\title{
Who Lead the School? The Influence of State Politics in School Leadership, Ethiopia
}

\author{
Elias Sebsibe Haile \\ Administrative and Development Vice Dean for Medical and Health Science College \\ Kotebe Metropolitan University \\ Brigitte Smit \\ Assistant Adjunct Professor- University of Alberta, Canada \& Visiting professor- University of Johannesburg
}

\begin{abstract}
Purpose- The purpose of this paper is to investigate nature of school leadership and the influence of politics in the public schools leadership process.

Design/methods/approach- Qualitative case study research design was used. In this research 24 teaches and 10 principals public secondary schools were purposefully selected. Semi-structured in-depth interviews were used to collect data from participants. Data analysis was done concurrently with the data collection process. Cods, categories and themes were extracted from the data and analysed.

Findings- Teachers' one- to-five group, education development/change army and school command post committees together were the core structure in school management and leadership activities. Principals were focus on coordinating and developing an 'educational army' in the school. The school principal has no mandate to make any decisions alone as it can be negated by the command post.

Originality/value- This research is one of the first empirical studies on the issue of political interference of the government in the school leadership. The study also the first to submitted for publication in international referred journals. The study findings are valuable for the theoretical development of school leadership and lessons will take for similar context.
\end{abstract}

Keywords- school leadership, command post, education development army, one-five group, principal, teacher, stet politics.

DOI: $10.7176 / \mathrm{JEP} / 11-25-03$

Publication date: September $30^{\text {th }} 2020$

\section{Introduction}

Education is considered as the tool for economic growth and social development of a nation. Aydin, Sarier and Uysal (2013:807) and Elias and Girum (2018:1) explain that education plays a pivotal role in the process of development and public transformation. One of its purposes is to produce highly trained and skilled human resources, which can sustain and accelerate economic and social development of a country (Elias \& Girum 2018:1).

To attain the goals of the school, the principal needs to engage in an effective leadership style to inspire and encourage teachers (Eyal \& Roth, 2011:271; Nir \& Hameiri, 2014). Thus, school principal leadership style has critical roles in the achievement of educational outcomes (Ibrahim \&Wahab, 2012). In harmony with this statement, Hallinger (2007) and Leithwood and Sun (2012:420) report that, in an educational organisation, in which appropriate leadership styles are used by principals and where the staff is highly motivated, the goals of the organisation are very likely to be achieved.

According to resources such as Abdo (2000), the Centre for British Teachers and VOS (2008) and Mengistu (2012), the education system in Ethiopia is currently challenged by a high teacher turnover, low number of capable teachers, and low levels of motivation, low teacher morale and poor quality of the working environment. Fekede (2015), Mengistu (2012) and Tesfaw (2014) have all reported that there is low level of teacher satisfaction and high turnover among public secondary school teachers. There seems to be a dearth of research in Ethiopia, which investigates the influence of principal leadership styles (instructional and transformational leadership) on teacher job satisfaction. In the area of educational leadership and specifically, school leadership variables such as political interference seems to be related to school management and leadership. However, these areas have not been intensely researched resulting in an empirical study gap in the area. Therefore, to fill the gap, this study has focused on an investigation of school management and leadership practice in public secondary schools of Addis Ababa, Ethiopia.

\section{Unique future of school leadership}

To achieve the goals of the growth and transformational development plan and good governance in Ethiopian sectors, effective implementation of civil service reform has been implemented. The main purpose of civil service reform is to develop civil servants who have the capability, knowledge, skills and common understanding of, and appropriate attitude toward governmental policies and strategies (Defere, 2016). In the same regard, public schools 
are one of the institutions that implement civil service reform. To ensure effective implementation of policies and strategies effectively three wings, the ruling party wing, the government wing, and the community wing, work

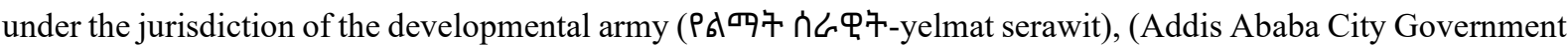
Human Resource Capacity Building Bureau, 2014).

The educational development army or the change army employs tactical arrangements to ensure that policies are implemented successfully. These include aspects such as the teacher one-to-five structure, the change army or development group, and the command post. The teacher's one-to-five structure is a governmental structure, a model or a network, where one member (leader of the group) is responsible for monitoring the activities of five more members. The group is organised by 4-7 teacher members within a department. The group leader of the one-to-five group is the one who has a good attitude towards and understanding of the government policies and strategies, most of the time he/she is member of ruling party. The one-to-five group leaders have the responsibility of organising the group meeting each week, setting the discussion agendas, preparing a plan for the group, reporting the weekly discussion and representing the one-to-five group at the change army group meetings. The leaders of one-to-five have the responsibility of shaping the attitude and developing the skills of the members in line with the government policies and strategies (Addis Ababa City Government Human Resource Capacity Building Bureau, 2014:4; Canada: Immigration and Refugee Board of Canada: Ethiopia, 2016). The change army/ development group is formed from two or above two one-to-five group leaders, thus a collection of one-to-five leaders. In secondary schools, the change army is organised according to related departments such as Social Science (History, Geography, Civics Education), Language Departments (English, Amharic), and Natural Sciences (Chemistry, Physics, Mathematics, Biology, Physical Education). The main responsibilities of the change army are to ensure good practice in each of the departments and solve problems that are raised in the one-to-five group meetings.

The command post in the school is the higher body that discusses every educational, political, community participation agenda and presents collective decision. The command comprises a school principal (as the chairperson), three vice-principals, change army leaders, and two teachers from the ruling party members.

The Ethiopian government starts to implement the above structures in schools in 2008 . However, limited research has been conducted on the school management and educational army development in school. Siyum and Gebremedhin (2015) conducted a study on the influence of politics on teacher's academic freedom and on the independence of academic institutions. The study found that the school principal, department heads and unit leaders are affiliated to the ruling party whereas teachers who were not in key positions as a result of not being involved in the party membership. Teachers need to become affiliated to the ruling party in order to be appointed to a position in the school or they are assigned to other sectors. Partiality was seen in schools where non-member teachers are not involved equally in professional development activities like training and upgrading of their education level. This means that in order to receive benefits, teachers are prompted to become members of the ruling party, which results in teacher's loss of their academic freedom which could influence the quality of education.

Finally, the study revealed that performance evaluation of teachers was highly dependent on political activities and lacked the focus of the teaching and learning process. Thus, teacher members of ruling party achieved greater evaluation points than the non-members. According to this study, political interference is the main reason for the professional dissatisfaction of teachers and the failure of schools to achieve their main objectives (Siyum \& Gebremedhin, 2015). In general, research on issues of political interference in educational leadership, in particular school leadership and teacher job satisfaction, have not been given due attention in the developing countries such as Ethiopia. The seemingly on-democratic political dictate from the top and state political interference is found in the country's schools. Investigating the impact of principal leadership behaviour in the given non-democratic context on teacher job satisfaction, may bring a different perspective to the literature. It is vital to explore the Ethiopian school experience with respect to school leadership styles and teacher job satisfaction in the context of the school management system and the macro-political discourse in Ethiopia.

Thus, the objective of this study is to understand the school management and leadership practice and the political influence in public secondary schools in Ethiopia.

\section{Research approach and design}

This research employs a qualitative instrumental case study research design. Qualitative method is allows the researcher to understand the feelings and interpret the lived experiences of study participants (Creswell, 2013; Merriam, 2002). According to Stake (1995), a qualitative instrumental case study research design is important to investigate a particular case in order to gain in-depth investigation into the researched issue.

Sampling

The participants of this research are principals and teachers of the public secondary schools. In this research 34 participants were selected, 24 teachers and 10 principals the sample of the study was selected by purposive sampling, which allows the researcher to perform a qualitative investigation under study (Creswell, 2013:155). 


\section{Data Collection}

Semi-structured individual in-depth interviews were used to collect data from participants. The in-depth interview is a common tool used for data gathering in qualitative research (Darlington \& Scott, 2002), allowing the researcher to understand and investigate the research issue.

Data Analysis

Data analysis was done concurrently with the data collection process. As the interviews were conducted in Amharic language, the interviews were translated to English language after the audio recorded data transcription. In this research ATLAS.ti 8 qualitative data analysis software will be used to facilitate the organisation of collected data. The data coding process and categorizing were used for developing themes to determine the research findings.

\section{Quality measures of rigour data}

In qualitative research to ensure the trustworthy and reliability of data is the vital issue. According to Rubin and Rubin (2012), establishing a good relationship with participants and ensuring the safety of participants are especially important. To maintain the quality of the research, trustworthiness techniques will be employed in the research process. Marshall and Rossman (2016) state that the trustworthiness of the research is ensured by applying methods such as: transferability, dependability, credibility and conformability techniques.

To improve the transferability of the findings, research techniques such as purposive sampling, the size of participants determined by the saturation of information obtained during data collection, thick description, establishing trust and conducting the interviews in the official language, Amharic(which all participants can speech well). Care taken for the research methodology, sampling selection, and data collection process and data audit trial were applied to ensure dependability of the study. To conform to the credibility of this research, efforts made during the process of sample selection, data collection and establishing a positive relationship with participants.

\section{Ethical considerations}

Permission was obtained to collect data from Addis Ababa City Government Education Bureau and public secondary schools. Moreover, the research participants were informed about the research purpose and objectives of the research. Then they were asked their willingness of participating in the interview. After the participant has asked their willingness to participate in the research, they were then asked to sign on the consent sheet. In this research, the name of the school and the name of participants were not specified. To minimise the risk and ensure the confidentiality, the interview time and site selected by the participants.

\section{Findings \\ Public School Management Structures}

The Ethiopian secondary school structure is comprised of four principals, three vice- principals and one chief principal or headmaster of the schools. This type of school structure was viewed differently by the research participants. Most participants supported the adopted school structure and the number of school principals. They argued that the larger number of school principals facilitates the school managerial routines effectively and enhances the quality of education. Supporting this, idea participants explained the structure as follows:

There are four principals, one head principal and three vice-principals. The first vice-principal focuses on the teaching process; the second vice-principal focuses on teacher's development; the third viceprincipal focuses on teachers' structure, which is the most recent one. This principal oversees speeding up the schoolwork, organising structures like the one-to-five grouping, the development army/BSC and other aspects of the school structure. (TP14)

Building on this explanation, a teacher further explained that:

The main one is the head principal; he/she is in charge of coordinating the three vice-principals and oversees the whole schoolwork. The first vice-principal is in charge of overseeing the teaching/learning process. The second one is in charge of the structural aspects of the school like, the one-to-five grouping and clubs. The third vice-principal is in charge of teacher progress and training teachers in continuous professional development (CPD) and balanced scorecards (TP12)

In addition to the management structure being composed of four principals, the other vital issue observed in the public secondary school management system was the involvement of stakeholders in school management activities. Three stakeholders were identified as being involved in the school management system. The first stakeholder is the government wing ( staff of the school who might or might not be members of the ruling political party. The government wing is responsible for activities such as pedagogical activities or usual school routines, assigned by the government. The positions held by members of this wing are often merit-based. The second stakeholder is the ruling party-political

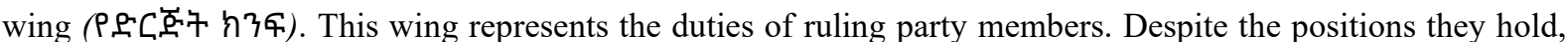
they are the cadres of the ruling party and even include the principals.

Teachers believe that the primary task of the cadres in the schools is to obtain information from school communities and give it to the principals of the school and the party official. The ruling party members often have 
regular meetings in the school to discuss current political issues. An example from an interview extract is given below.

The school is led by the coordination of three administrative wings. These are a political wing (the governing ruling party members), community wing (Students' parents), and Government wing. (TP2).

Similarly, principals also confirmed that they mainly focus on the political agenda that the ruling party dictates. They are highly engaged in recruiting and organising members of the ruling political party, discussing political issues in the school and reporting the political activities organised inside and outside the school. Even though the school has four principals (one head principal and three vice-principals), all of them seemed to focus on coordinating and developing an 'educational army' in the school. The principals are evaluated by the AACA subcity officials based on the effectiveness of the school in developing the 'educational army', such as monitoring one-to-five teams. They also work hard at changing teachers' attitude toward to the ruling political party. Principals are not evaluated based on the effort they make in enhancing student achievement and ensuring quality education. The following extract offers some explanation:

The head principal focuses on politics and public relation tasks. I, most of the time, was working on the political issues that were directed by AACA sub-city officials. I reported about my school 'developmental army' building, one-to-five grouping, 'command post' activities and other activities of party members every week to the political wing. The vice-principals are oversee assembling and coordinating the political activities, co-curricular activities, one-to-five networking and 'educational army' development in the school. They also manage human resource issues and work with the Student Council. (PP01).

To ensure effective implementation of policies and strategies in schools the ruling party wing, the

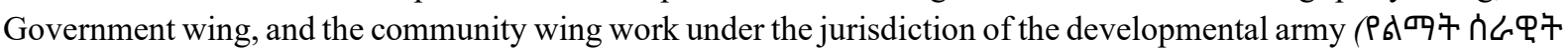
Yelmat serawit) (Addis Ababa City Government Human Resource Capacity Building Bureau, 2014). The development army or the change army employs tactical arrangements to ensure that policies are implemented successfully. These include aspects such as the command post and the teacher one-to-five structures both of which are discussed below.

\section{Command post: a tool for political interference}

The command post is a unique administrative structure, which includes the different bodies of the school community such as the government wing, the political wing, and the community wing. It is comprised of principals, selected teachers who are members of the ruling party (politically affiliated teachers) and the head of the change army. As participants in this study explained, the command post of the school makes every decision and serves as a centre of command in the school. It is a centralised system of management and has disproportionate power in the school. The school principal has no mandate to make any decisions alone as it can be negated by the command post. In this regard, principals who participated in this study commented on the issue as follows:

Command post means a military headquarter where you give orders. Therefore, teachers claim that the name by itself is wrong and should not be used in the school as teachers are not soldiers. Instead, it should be called the school bylaws. The phrase has a political connotation. The Government implemented the command post in schools to put teachers under pressure. This is against academic freedom. Most of the teachers were dissatisfied by political interferences in the education system. The 'command post' is used to lead and organise departments. The principals and department heads are part of the 'command post' lead the teaching and learning processes in the school. ( PP 001)

School principals are not happy with the involvement of the command post structure in the school leadership as it tends to prevent the autonomy of the principals to exercise their leadership roles, leadership style and decisionmaking powers in the school. Every managerial activity, teaching and learning process is implemented under close control of the command post and as a result, the interference of the command post in school management is considered a problem by teachers. Regarding this, a participant explained that:

The politics are holding the directors back not to perform their duties on full scale. As all the decisions concerning the school's matters are made by higher Government officials, there is less power among teachers and school directors to make decisions and bring changes in schools. There are also committees (command post) who will decide on some small matters in the school. (TP4)

Sometimes, the level of interference goes further to checking the classroom interaction, where teachers are asked about their classroom interactions. Trust between the managing body and teachers have been broken, as articulated by a teacher: there is high suspicion and lack of freedom among teachers. This hurts teachers' job initiation (TP8). As the working relationship is tainted with distrust and apprehension, teachers' feelings towards school and their work have changed and they feel side-lined. Another teacher supports this idea: Teachers are not involved in any of the decision-making. Most of the every decision is sent from the upper level management. Its somehow feels like a military command. (TP9)

Structurally, school leadership is organised by one principal, three deputy principals, department heads and 
administration wing heads (finance unit, human resource unit, purchasing unit, and material and general service unit). These represent the school managing committee and lead the school activities. However, without dismantling this managing body, the government has organised another school managing entity called the command post. The command post is organised by the school principals (principal and his/her deputies), with the social science department having one representative, the natural science department one representative, the language department

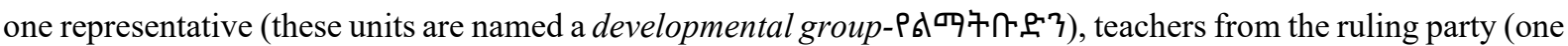
from each front) but in contrast to the legal structure of the school managing body, it has more political power. In some cases, a representative of the teachers, a police officer from a nearby police station, and a representative of students are added to the command post. All members of the command post are expected to be ruling party members.

\section{Teachers' one-to-five grouping: a controlling strategy}

Teachers are organised in groups, named one-to-five grouping to facilitate the teaching and learning process. Every teacher in the school is integrated into a network of one-to-five. The structure is composed of a minimum of four and a maximum of seven teachers in a group. Of the group members, one teacher is selected to lead the one-to-five grouping. The leaders of one-to-five-groups are senior members of the ruling party (ginbare-kedem,

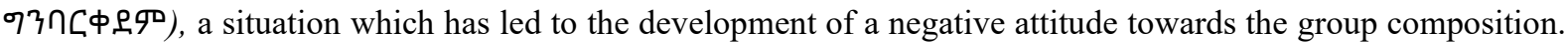
Teachers perceive the structure as the political tool designed by the Government to interfere in the management of the school system.

Teachers are organised in groups. However, teachers do not want to participate in one-to-five groups. They believe that it is useless to participate in such groups. They think that the Government organised teachers in one-to-five groups for the sake of politics. They do not believe that participating in one-to-five groups improves the quality of education. (TP3).

However, another teacher sees the one-to-five group structure in a different light, although he/she does report on resistance found with acceptance of the grouping:

I believe that if teachers work based on one-to-five groups, there will be a change. They can use cooperative teaching techniques to teach their students. The teachers can also use it to solve their problem, to share their experience of teaching, to implement the same kinds of teaching methods. Teachers must report what they have got from one-to-five group discussion. ( TP4)

Some teachers see the positive effects that the group interactions could have on teaching. A few teachers perceived the one-to-five grouping approach as important to improving the quality of education if the school management implemented the discussions properly and followed its implementation. Using weekly meetings to discuss educational issues would assist teachers in finding solutions to problems they face during the teaching and learning process. The grouping would also create good opportunities to share their experiences. Moreover, the grouping helps to fill knowledge, skill, and information gaps of the teaching staff. In this regard, one participant reported that:

If teachers believe in the importance of participating in one-to-five group discussions, they will be highly effective in improving students' performance. However, the teachers did not want to take part in the group discussions. They give many reasons for this. They say that the Government introduced one-to-five group discussions to control teachers' political involvements. They also say that teachers' responsibility should be teaching. The teachers believe that participation in one-to-five group discussions is a waste of time as it takes too much time. Instead, they worked in other private schools as a part-timer to earn more money to support them. (TP4).

Some teachers perceived the one-to-five structure as time-consuming. The group needs to meet every week and prepare a plan and report on every meeting. Teachers do not want to engage in meetings and feel that they are wasting their time in one-to- five activities. Many teachers often leave school as soon as they have finished teaching, particularly as they are working at additional part-time jobs to supplement their salaries, which are minimal and do not cover family expenses:

Many teachers are not interested in participating in one-to-five group discussions. It is not only ineffective but also monotonous and boring. Many teachers have two or three extra part-time jobs outside the school as they have received poor pay, and it could not cover their house rent and other expenses. Few teachers perceived the one-to-five groups as an important tool for the effectiveness of school management. (TP15).

Another participant agreed that the meetings are time-consuming and the content is not educationally based:

We discuss irrelevant issues in our one-to-five group discussions. For example, we discuss the country's current situation and political turmoil happening in the country and ways to protect our students and teachers from being involved in the conflicts. We also discuss ways to avoid conflicts among students in the school compound. (TP5)

Although many teachers reported that participating in one-to-five meetings is mandatory to ensure better results in their performance evaluation, they also mentioned that one-to-five discussions might or might not be 
important for improving the teaching and learning process and quality of education. But it seems that the school management body focused only on whether the discussions were held or not, calculating the amount of time spent on one-to-five discussions and checking the report received from the group leaders. If the discussions were conducted and reported on every week, the members of the groups would get a better score during annual performance efficiency evaluation. One teacher reported that:

There are one-to-five groups in our school. There is a weekly meeting among the groups. We already told the administrators that teachers participate in one-to-five group discussions as they fear them. We are not allowed to oppose and be absent from the group discussions. Authorities already told us that anyone who does not want to participate in and who wants to oppose one-to-five discussions should leave his/her job immediately. Though teachers do not believe in the importance of one-to-five groups, as they fear the school leadership, they meet and write false reports. (TP6).

Another teacher asserted the same:

If teachers did not participate in one-to-five group discussions, they would be given a poor score in their performance evaluation result. Then, it becomes a matter of survival for teachers. Therefore, teachers prepare false minutes and reports and submit them to the principals. The principals know the situation. As they are forced to accept the program, they want teachers to prepare a false report and submit it to them. School competed with other schools based on the reports they submit. (TP5).

Teachers remarked that they have no interest in participating in the one-to-five grouping. It was perceived that such groups are used as political instruments to manipulate and control teachers in the schools. The grouping is used to suppress the academic freedom of teachers in the schools. Furthermore, one-to-five group members are expected to meet every week to discuss issues that do not have any relation to the teaching and learning process. This made discussions boring and time consuming. The participant further explained that:

Teachers do not like to participate in one-to-five group discussions. The discussions were full of problems. The main cause is that teachers have many academic activities that they should be engaged in. Besides, they are expected to meet every week and take minutes and report it to the principals. If teachers did not participate in one-to-five group discussions, they would be given a low grade in their performance evaluation result. Therefore, it is a matter of survival for teachers. Therefore, they prepare false minutes and reports and submit them to the principals. The principals were conscious of the situations. As they are forced to accept the system, they want teachers to prepare a false report and submit it to them. Obviously, principals know that their school competes with other schools based on the reports they submit (TP5)

Another teacher mentioned that assigning teachers in one-to-five groupings created distrust between teachers and the government. The structure does not function in enhancing the quality of education in the schools. It is used instead for spying on teachers' day-to-day life and their attitude towards the ruling party:

Teachers disagree with the objective of one-to-five grouping. They believe that the Government designed to introduce its politics in schools and to control teachers. As teachers have no options, they participate in one-to-five group discussions. It has no use for teachers. (TP5).

Every staff member in the school must participate in one-to-five groups. According to the Addis Ababa City Government Human Resource Capacity Building Bureau (2014:4), organising teachers into such groups facilitates the management of school activities, creating smooth and fast communication. Such groups are also useful in identifying the strengths and weaknesses of teachers and building their capacity. Groups also facilitate experience sharing and control of teachers. However, the participants do not really understand the mission of the one-to-five structure. Their perception of the one-to-five structure is not aligned with the government's aim.

\section{Principal selection and assignment based on political affiliation}

In the Addis Ababa City Administration (AACA) public secondary schools, the principals are selected and assigned based on their political commitment. Most responding teachers believed that principal positions were filled by ruling party members. Principals have been given political missions in the schools. Many teachers believed that the Ethiopian education system is highly governed by the politics of the government although schools are expected to be independent (Siyum \& Gebremedhin 2015:223-235).

A teacher asserted that:

School principals are politically appointed to schools though they do not have the necessary education for the position. Then, once they seized the positions, the Government facilitates sponsors for them to attend university education to get the necessary qualification. This is the main cause for teachers' disappointment... Principals are assigned to the school for achieving the political mission that they have been given. (TP4).

On the other hand, a principal participant stated that there is an improvement concerning school principal selection and assignment. He further explained that the City Administration has begun to assign principals on a merit basis. He said that he was assigned based on merit and qualification. However, the participant did not deny 
the fact that political affiliation has been a fundamental factor for assignment to principal postions. He explained that:

The selection and recruitment of principals are very vague. Some of us got this position by recruitment and selection, but the others are politically assigned. Previously, principals were directly appointed to schools without considering their qualifications. Nowadays, the vacancy is posted, and anyone who qualifies for the post can apply and compete based on the civil service rule and regulations. (PP01)

In some instances, school principal selection seems merit-based, but it is not without political influence. A teacher who wants to become a principal can apply for the position. However, the one who applies must have a positive recommendation from the command post committee of the district (Woreda) education bureau. The District (Woreda) command post committee constitutes the pro-ruling party member. Their main task is to screen the teacher applicants for principalship, evaluating applicants' political history, their participation, and contribution as a political member in the ruling party. Regardless of the educational qualification of the applicant, the command post committee will only submit a recommendation letter for the applicant who is a ruling party member. Applicants who are not members of the ruling party are rarely given the chance to pass the selection criteria and get a recommendation letter. There are rare cases where teachers, who are not the political party members, are selected. If the selected principal is not a member of the political party, the sub-city education officials push the principal to become a ruling party member. If the principal is not willing to be a ruling party member, they select a teacher who is a ruling party member and replace him/her. Regarding this issue, Participants 1,9 and 11 asserted:

Concerning the appointment of the school director, the school director should be a member of the governing political party to be appointed as a school director. His/her educational qualification and leadership competence are not considered a major criterion. Being a member of the governing party is a major criterion, so this disappoints the most of teachers in the school. (TP1).

Another principal also asserted that:

The principals are appointed after they have competed with others, but no one gets a fair chance for the position. If the person gets a letter of recommendation from the district/Woreda/ command post, he or she has a great chance to be principal. On top of this, your political affiliation to the ruling party also matters. If you are a member of the leading political party, you have high chances to be selected. Therefore, the sub-city command post will evaluate the letter from the district 'Woreda' command post committee and appoint the principal based on the information received from them. (PP17)

Participant 13 also stated that the presence of political interference in the appointment of school principals makes teachers perceive principals as incapable of leading schools effectively. Thus, the relationship between principals and teachers is poor. The trust between the teachers and the principal is deficient, so teachers do not cooperate with their principals. The participant said that: As teachers believe that their principals are not professional but rather are politicians, they are not willing to cooperate, (TP5)

Findings also suggest that politics runs deep in the school structure. Regarding this issue, one of the participant teachers reported the following: Among the four school leaders, one works on organising teachers in different activities of the ruling political party (TP8), acknowledging that the responsibility of structural vice- principal is to organise the hidden political structure that supports the ruling party, such as recruiting teachers and administration staff to be ruling party members, organising the political meetings at the school and gathering political information from students as well as from teachers, organising the one-to-five structures and the educational change army. The vice principal leads the political activity in the school. The same participant gave his opinion as follows:

It is purely political activity. The principal organises teachers into four political parties of EPDRF: OPDO (Oromo People Democratic Organization), TPLF (Tigerian People Liberation Front), ANDM (Amhara National Democratic Movement) and SNNPDF (South Nation and Nationality People Democratic Front). (TP8).

Moreover, a teacher revealed that:

Out of the four principals, one of them is vice-principal of the structural sector, which purely does political activities. The main aim of this vice-principal is to formulate and lead the political structures. It is said that this vice-principal coordinates the 'co-curricular clubs', but this is just a cover; his main aim is to make sure the policies of the ruling party were implemented inside the school compound (TP10).

The principal, who participated in this research, also explained that the focus of the school principal was mainly to organise, support and discuss the politics in the school with the ruling party members. They also work to identify teachers who oppose or stand against the Government's political ideology as well as the overall activities of teachers in the school. The school principal has the responsibility to strengthen the one-to-five grouping, the command post, and school development army roles in the school. If there are some irregularities or defects in the political structure of the school, the principal is held responsible. His/her survival in the school is under question. This is because the performance evaluation criteria of the principals are based on how strongly 
involved the school members are in political activities such as establishing one-to-five grouping and creating an effective developmental army to support education in the school, "yetemhirte limat serawit ginbata"

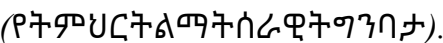

\section{Principals' lack of autonomy to manage the schools}

Most teachers believe that their principals are assigned based on their political affiliation with the ruling party. Thus, teachers have no trust and confidence in their principals' skills to lead their schools. They believe that their principals have no capacity and ability in educational leadership. On the other hand, teachers who are members of the ruling party interfere in the principals' activities. Such teachers dominate decision making by the school administration. In such schools, principals are not autonomous in decision making. In this regard, a teacher mentioned that:

Teachers also have low confidence in their principals as they believe that the leadership has no power and confidence to decide on matters. This is because those teachers who are members of the ruling party informally act on behalf of the principals and decide on matters in the school. (TP1)

This finding is also supported by the study of Siyum and Gebremedhin (2015:223-235), who found that there is a significant relationship between position and the politics of ruling party membership in the schools. Moreover, pointed out that there is a group called the 'political wing' which includes teachers who are party members. This political wing is dominant in that it is responsible for every decision that is made in the schools. The principal has no autonomy to decide on school matters without consulting the political wing of the school.

Similarly, another teacher asserted that:

The political wing serves as a mediator between schools' leadership and the schools' community. Members of such a wing provide information about teachers whether they are doing their job or not. They also check whether Government policies are implemented properly. In addition, they have a role in the management committee. They plan an evaluation session in the command post. Generally, these teachers have high decision-making power in their schools.( TP2).

According to Seashore, Leithwood, Wahlstron and Anderson (2010), school principals are the ones who have the power and leadership autonomy in the schools. Practising leadership, making decisions and setting the vision of the school is the primary function of school principals. However, the autonomy of school principals in Addis Ababa City Administration public secondary schools has been violated by the political unit called the command post in the schools, the ruling party members presence in schools and the education bureau officials. Principals do not have the freedom to make decisions; they have to consult with others, and as such others will make the final decision.

\section{Principal focus on political activities}

Effective leadership can make a difference in schools with school climate and environment and is essential in improving the efficiency and equity of schooling. (Pont, Nusche \& Moorman, 2009:9). However, this study found that schools in Addis Ababa City Administration area are not achieving their mission. Political activities are given more emphasis than the teaching and learning activities. Furthermore, Participant 12 stated that school principals do not focus on achieving quality education. It seems that principals spend most of their time in their offices preparing reports and seeing to routine paperwork, which leaves them with little extra time to follow and support the instruction in their schools. The principals' involvement in the instructional activities such as instructional supervision, motivating students for better achievement, managing instructional time, developing and revising the curriculum, and engaging in co-curricular activities were found to be minimal. It seems that delivering quality education is not the central issue for the principals. This idea is backed by a Participant P 16 who said that:

Instead of focusing on the teaching/learning process, principals focus on delivering urgent political reports that are demanded by a higher authority. Moreover, staff meetings which they organize usually focus more on political- related issues than the school establishment. (TP16).

Another teacher also claimed that:

They only focus on the political mission they have been given instead of leading their schools in a proper way. (TP8).

Taking the idea further, a teacher remarked that:

There are political structures in schools. A party entity organises political assemblies and provides guidance regarding the four national parties that form the ruling party. There is usually an assembly in which the participants are political members inside the school. The members of this group have political affiliations and strong ties with the administration. TP10).

Teachers believe that there is political interference from the ruling party in their schools. Accordingly, political interference affects the teaching-learning process and ultimately the performance of teachers and student outcomes. Teachers reported that school principals force them to accept the ruling party ideology and become members. As a result, they set regular meetings to discuss issues related to politics. In this regard, a teacher stated 
that:

There is political interference in the schools from the governing party. We are always told that the main target for having regular meetings is to bring the same and common thought among teachers about Government policy. This means that teachers should follow the Government political ideology. We are not allowed to think differently. In those regular staff meetings, there is no academic agenda which raises issues related to our profession, but all meetings focus on politics.(TP6).

According to the research participants, public secondary schools in Addis Ababa are suffering from political interference. Principals have little or no freedom to lead the school based on their leadership style. Every managerial decision is made in consultation with the command post of the school. The school plan, vision, mission and objectives are applied as a top-down approach. Principal performance evaluation also focuses on school political activities, not on instructional/teaching achievement. In this regard, the leadership system of the school seems to be centralised and led like a military command.

\section{Political affiliation determines the relationship in schools}

Most of the school principals are members of the ruling party. Their main objective is to convince and recruit teachers to join the ruling party as members. To do this, principals establish a close relationship with teachers who are party members. As a result, two groups of teachers exist in schools. One group of comprises teachers who are not members of the ruling party and a result, are considered an opposition. The other group is composed of those who are members of the ruling party. Teachers in the second group are granted favours in different forms even though they are not in possession of the appropriate knowledge and skills. In line with this, a teacher explained that equity between the two groups causes tension:

There are two groups of teachers in the school. These teachers are either political party members or not. Those who are not members of a political party have a feeling of being neglected by the Government. This is because many teachers who are party members were seen being selected to be a principal regardless of their leadership skills or work ethics. On the other hand, those who are not party members but have good leadership skill and work ethics for the position of a principal might fail to get the chance to be selected. This scenario has created many grievances among teachers because they were not treated equally. (TP22)

A teacher reveals that the relationship among the staff of the school is mainly based on their political attitude. If a teacher is a member of the ruling party his/her communication is with teachers of the same political affiliation. Groups were created in the school community; but this was not done to engage with common goals. Usually, the principals are the member of the ruling party, and they support the teachers who are party members.

There is a good relationship among member of governing political party. There is a poor relationship among teachers who are not members of a political party. There is a deliberate division and partiality among teachers (TP8)

Principals are assigned as political appointments, and as a result, their potential as a leader is under question. As there is a political agenda in schools, there is no trust and little communication between principal and teachers. In such cases, it is challenging to ensure the quality of education.

\section{Recommendations}

Public secondary school's management system was affected by the ruling party politics despite any legal support, and this contrary to the Ethiopian Constitution. This illegal and unpleasant situation resulted in low quality education. More specifically, structures like 'command post', 'developmental army' and 'one-to-five' were perceived by public secondary school teachers as political tools for the ruling party to manipulate schools. These structures have made schools ungovernable by exercising a hidden political agenda. Thus, the government should protect schools from political interferences. Schools should have the autonomy of academic freedom. Educational stakeholders such as the government, school leaders, student parents and the Ethiopian Teachers Association should work together to fight political interference in schools. Ensuring that schools are freed from political interference does not mean only from the ruling political party but also from the opposition parties as well. Schools should be has academic freedom to provide quality and relevant education.

\section{Implications}

This study was undertaken before the political transition in the country. Currently Ethiopia has new government and government system. Thus, I recommend for further research on the political transition may change the school management and leadership.

\section{Conflict interest}

The authors declared no potential conflicts of interest with respect to the research, authorship, and/or publication of this article. 


\section{References}

ABDO, H.A. 2000. Teacher incentives in the Middle East and North Africa Region: The shortcomings. Mediterranean Journal of Educational Studies 6(1):107-122.

ADDIS ABABA CITY GOVERNMENT HUMAN RESOURCE CAPACITY BUILDING BUREAU 2014. Change Army and One to Five Organizing procedures regulation,

AYDIN, A., SARIER, Y.\& UYSAL, S. 2013. The effect of school principals Leadership style on teachers' organizational commitment and job satisfaction. Educational Science: Theory \& Practice 13(2): 806-811.

BUSH, T. 2007. Educational Leadership and Management: Theory, Policy, and Practice. South Africa Journal of Education. 27(3):391-406.

BUSH, T. \& GLOVER, D. 2014. School Leadership Models: What do we know. School Leadership and Management: Formerly School Organization, 4: 553-571.

BUSH, T. 2008. Leadership and Management Development in Education. London: Sage Publications.

CANADA: IMMIGRATION AND REFUGEE BOARD OF CANADA, ETHIOPIA: 2016. Information on "1 to 5" groups in Ethiopia, including origin and purpose; whether citizens are required to participate in them; consequences for refusal. From: https://www.refworld.org/docid/5a8405244.html (accessed 10 April 2019).

CRESWELL, J.W. 2013. Qualitative Inquiry and Research Design: Choosing Among Five Traditional Approach. 3rd edition. Thousand Oaks, CA: SAGA.

DARLINGTON, Y. \& SCOTT, D. 2002. Qualitative Research in Practice: Stories from the field. Australia, Allen \& Unwin.

DEFERE, G. 2016. Civil Service Reforms and Service Delivery: A Case Study of three Service Providing Public Institutions in Jimma City, South West Ethiopia. Journal of Good Governance and Sustainable Development in Africa, 3(2):72-81.

EDUCATION FOR ALL (EFA) REPORT (ETHIOPIA). 2015. Education for All National Review Report. Ethiopia. From: efa2015reviwes@unesco.org (accessed22 March 2017)

ELIAS, S.H. \& GIRUM, S.T. 2018. Demand and Intake Capacity in Selected Departments of Postgraduate Studies in Addis Ababa University. Journal of Education and Practice. 9(22):20-25.

EYAL, O.\& ROTH, G. 2011. Principals' leadership and teachers' motivation. Journal of Educational Administration, 49(3): 256-275.

FEKEDE, T.G. 2015. Exploring teachers' motivation for teaching and professional development in Ethiopia. Journal of Studies in Education, 5 (2):169-186.

HALLINGER, P. 2007. Leadership for Learning: Reflections on the practices of instructional and transformational leadership. Paper presented, Seminar at East Asia University.

HARRIS, A.\& JONES, M. 2010. Professional learning communities and system improvement. Improving Schools, $13: 172-181$

IBRAHIM, M.S. \& WAHAB, J.A. 2012. Educational Leadership. Bangi: University

Kebangsaan Malaysia.

LEITHWOOD, K. \& SUN, J. 2012. The nature and effects of transformational school leadership: A Meta-analytic review of unpublished research. Educational Administration Quarterly, 48 387-423

MARSHALL, C. \& ROSSMAN, G.B. 2016. Designing qualitative research. 6th edition.Thousand Oaks, CA: SAGE.

MENGISTU, G. K. 2012. Job Satisfaction of Secondary School Teachers in Ethiopia.

MERRIAM, S.B. 2002. Qualitative research in practice: Examples for discussion and analysis. San Francisco, CA: Jossey-Bass.

MINISTRY OF EDUCATION (MoE). (2010). Education Sector Development Program IV (ESDP IV) $2010 / 2011$ 2014/2015 2003 EC_2007 EC. Addis Ababa: Ministry of Education.

NIR, E.A., \& HAMEIRI, L. 2014. School Principals Leadership Style and School Outcomes. Journal of Educational Administration, 52(2):210-227.

$\mathrm{PhD}$, Dissertation. University of South Africa.

PONT, B., NUSCHE, D., \& MOORMAN, H. 2009. Improving School Leadership V. 1: Policy and Practice.OECD

RUBIN, H.J., \& RUBIN, I.S. 2012. Qualitative Interviewing: The art of hearing data. Thousand Oaks, CA: SAGE.

SEASHORE, K., LEITHWOOD, K., WAHLSTRON, K.L., \& ANDERSON, S.E. 2010. Investigating the link to improved student learning report of research findings. New York: Wallace Foundation.

SIYUM, A.B.\& GEBREMEDHIN, M.A. 2015. Teachers in Politics: Impact of Political Party Membership on Teachers' Freedom \& Stability. The Case of Nigste-Saba High School, Adwa, Tigray, Ethiopia. Journal of Education and Practice 6 (13):223-235.

STAKE, R.E. 1995. The art of case study research: perspectives on practice. $2^{\text {nd }}$ edition. Thousand Oaks, CA: SAGE.

TESFAW, T.A. 2014. The relationship between transformational leadership and job satisfaction: The case of 
government secondary school teachers in Ethiopia. Educational Management Administration \& Leadership 42(6): 903-918.

VOLUNTARY SERVICES OVERSEAS (VSO). 2008. How much is a good teacher worth? A report on the motivation and morale of teachers in Ethiopia. London: VSO.

WAHAB, J., FUAD, C., ISMAIL, H.\& MAJID, S. 2014. Headmaster transformational leadership and their relationship with teachers' job satisfaction and teachers' commitments. International Educational Studies, 7(13):40-48

YIN, R.K. 2014. Case Study Research: Design and Methods. 5th edition. Thousand Oaks, CA:SAGE. 